\title{
TOXICITY OF INSECTICIDES USED IN MUSKMELON ON FIRST-INSTAR LARVAE OF Chrysoperla genanigra FREITAS (NEUROPTERA: CHRYSOPIDAE) ${ }^{1}$
}

\author{
BÁRBARA KARINE DE ALBUQUERQUE SILVA ${ }^{2 *}$, MAURÍCIO SEKIGUCHI DE GODOY ${ }^{2}$, ALRICÉLIA GOMES \\ DE LIMA $^{2}$, ANNA KÉZIA SOARES DE OLIVEIRA ${ }^{2}$, PATRIK LUIZ PASTORI ${ }^{3}$
}

\begin{abstract}
Brazil is one of the world's largest producers of melon (Cucumis melo L.), and Rio Grande do Norte and Ceará are the largest producers states of the country (99\% of exports). This crop had great socioeconomic importance in the Brazilian Northeast, however, it is affected by insect pests and consequently, large amounts of pesticides are applied to it, which greatly affect beneficial organisms, such as Chrysopidae. This bioassay evaluated the toxicity of nine insecticides used in commercial crops of muskmelon, applied to firstinstar larvae of Chrysoperla genanigra of up to 24-hour-old, from mass rearing cultures. Sublethal effects were evaluated, classifying the insecticides into the toxicity classes recommended by the IOBC. A completely randomized design was used, consisting of ten treatments (clothianidin, pymetrozine, lambda-cyhalothrin, chlorantraniliprole, indoxacarb, pyriproxyfen, beta-cyfluthrin+imidacloprid, imidacloprid, beta-cypermethrin and a control consisted of distilled water). The treatments consisted of exposure of thirty larvae to dry residues of each product in Petri dishes, assessing their mortality, duration of instars, sex ratio, fecundity and viability of eggs from adults of the insects evaluated. The products were classified in toxicity classes as harmful (Class 4) (clothianidin, pymetrozine, indoxacarb, lambda-cyhalothrin, beta-cyfluthrin+imidacloprid, imidacloprid, betacypermethrin and pyriproxyfen) and innocuous (Class 1) (chlorantraniliprole) to first-instar larvae of $C$. genanigra, by calculate their total effect. Based on this work, chlorantraniliprole is the only recommended insecticide for use in integrated pest management (IPM) programs in muskmelon crops.
\end{abstract}

Keywords: Green lacewings. Predator. Cucurbitaceae, MIP.

\section{TOXICIDADE DE INSETICIDAS UTILIZADOS NO MELOEIRO SOBRE PRIMEIRO INSTAR DE Chrysoperla genanigra FREITAS (NEUROPTERA: CHRYSOPIDAE)}

\begin{abstract}
RESUMO - O Brasil é um dos maiores produtores de melão (Cucumis melo L.), tendo os estados do Rio Grande do Norte e Ceará os maiores representantes ( $99 \%$ das exportações), com enorme relevância do ponto de vista socioeconômico para a região nordeste. No entanto, a cultura é acometida por insetos-praga, razão pela qual grandes quantidades de agrotóxicos são necessárias os quais afetam sobremaneira organismos benéficos como os crisopídeos. O bioensaio avaliou a toxicidade de nove inseticidas utilizados comercialmente na cultura do meloeiro, aplicados sobre primeiro instar larval de Chrysoperla genanigra, avaliando, inclusive, efeitos subletais, categorizando os inseticidas em classes de toxicidade preconizadas pela IOBC. Foram utilizadas larvas com até $24 \mathrm{~h}$ de idade, oriundas de criação massal. Utilizou-se o delineamento inteiramente casualizado, composto por dez tratamentos: clotianidina, pimetrozina, lambda-cialotrina, clorantraniliprole, indoxacarbe, piriproxifem, beta-ciflutrina + imidaclopride, imidaclopride, beta-cipermetrina e a testemunha constituída de água destilada. Cada tratamento consistiu na exposição de trinta larvas aos resíduos secos de cada produto em placas de Petri, realizando-se avaliações de mortalidade, duração de instares, razão sexual, fecundidade, bem como a viabilidade dos ovos produzidos pelos adultos provenientes dos insetos testados. Pelo cálculo do efeito total, os produtos foram enquadrados em classes de toxicidade: clotianidina, pimetrozina, indoxacarbe, lambdacialotrina, beta-ciflutrina + imidaclopride, imidaclopride, beta-cipermetrina e piriproxifem como nocivos (Classe 4) e, lorantraniliprole como o único produto inócuo (Classe 1) à fase testada, sendo este o único com base neste trabalho recomendado para uso em programas de MIP no melão.
\end{abstract}

Palavras chave: Crisopídeo. Predador. Cucurbitácea. MIP.

\footnotetext{
*Corresponding author

${ }^{1}$ Received for publication in $05 / 18 / 2016$; accepted in $10 / 20 / 2016$.

Paper extracted from the monography of the first author.

${ }^{2}$ Department of Plant Sciences, Universidade Federal Rural do Semi-Árido, Mossoró, RN, Brazil; babialbuquerqueS@hotmail.com, msdgodoy@ufersa.edu.br, alricelialima@hotmail.com, annakezia@outlook.com.

${ }^{3}$ Department of Phytotechny, Universidade Federal do Ceará, Fortaleza, CE, Brazil; plpastori@ufc.br.
} 


\section{INTRODUCTION}

Rio Grande do Norte (RN) is one of the largest producer and exporter Brazilian states of muskmelon (Cucumis melo L.) (ARAÚJO; CAMPOS, 2011). However, this state has limiting factors to production that can compromise entire crops, especially the occurrence of insect pests like the whitefly [Bemisia tabaci biótipo B (Hemiptera: Aleyrodidae)] and the leaf-miner fly [Liriomyza spp. (Diptera: Agromyzidae)] (SOBRINHO et al., 2011).

The suppression of these arthropods through chemical control is still the main method of control (LIMA et al., 2012). However, despite the relative efficiency of insecticides in the production chain, they cause irreparable environmental problems, especially related to incorrect and overdose applications. Therefore, the development of alternative methods to control agricultural pests, such as the biological control, has become increasingly promising for inclusion in integrated pest management (IPM) programs (CHAGAS et al., 2016).

Biological control has been used as one of the main methods in IPM programs, because it is environmentally safe and efficient in regulating phytophagous populations. The occurrence of natural enemies of insect pests, such as the Chrysopidae (Neuroptera: Chrysopidae), found in muskmelon crops generated perspectives for the use of these organisms in agricultural areas (LIMA; BUENO; ALENCAR, 2013).

The Chrysopidae stand out among the various biological control agents because, according to Freitas (2001), they are very voracious predators with ample predation capacity of various pests and are present in various important agricultural crops.

Foerster (2002) reported indirect effects, resulting from direct contact of natural enemies of insect-pests with insecticides or insecticide residues, such as reduction of hosts and preys, in addition to sublethal effects. Control methods using a tritrophic system, consisting of the combined used of natural enemies of insect pests, selective insecticides and resistant host plants is necessary to minimize these effects. Moreover, the use of selective insecticides is one of the basis for a well-established IPM program, and an important tool for conservation of populations of natural enemies of insect-pests in agroecosystems (PICANÇO, 2010).

Chrysopidae are also easily reared in laboratory and have high reproductive potential and selectivity to many pesticides, favoring its use in IPM programs (SOARES; ALMEIDA, 2001).

About 1200 species of Chrysopidae has been recorded in the world (BROOKS; BARNARD, 1990), among which 82 species have been reported in Brazil associated with agroecosystems (FREITAS; PENNY, 2001). According to Freitas and Morales (2009) Chrysoperla is one of the most important genus in the country, since from the 36 species of this genus, four were found in Brazil, and among these species is the $C$. genanigra, which was found only the muskmelon crops in the region of Mossoró RN. However, studies on selectivity to insecticides on $C$. genanigra are scarce and not yet published, and most studies on this genus are concentrated on the species C. externa (CASTILHOS et al., 2014) and C. carnea (MAIA et al., 2016). Thus, the conduction of research on $C$. genanigra, especially regarding the effect of phytosanitary products on different development stages of this insect, is essential for its conservation and introduction into agroecosystems.

In this context, the objective of this work was to evaluate nine insecticides, used in commercial crops of muskmelon, on the first-instar larvae of $C$. genanigra.

\section{MATERIAL AND METHODS}

The bioassays were conducted in the Chemicals Selectivity Laboratory of the Federal Rural Universidade Federal Rural do Semi-Árido (UFERSA). The insects used were from the F6 generation of the laboratory mass-rearing. The methodology followed the standards described by the International Organization for Biological and Integrated Control of Noxious Animals and Plants (IOBC) (IOBC/WPRS, 1992; HASSAN et al., 1994).

The commercial names, active ingredients, concentrations used and chemical group of the products evaluated are described in Table 1 . The effect of the contact of first-instar larvae of $C$. genanigra of up to 24-hour-old with the surfaces treated with the insecticides and control (consisted of distilled water) was evaluated in $10-\mathrm{cm}$-diameter Petri dishes that received these treatments and were left to dry for two hours. A $500 \mathrm{ml}$ manually pressurized sprayer with flow of $0.58 \mathrm{ml} \mathrm{sec}^{-1}$ and an average application rate of $1.5 \pm 0.5 \mathrm{~mL}$ of solution $\mathrm{cm}^{-2}$ was used for the insecticide applications. The larvae were individualized on the dishes and kept at temperature of $25 \pm 2{ }^{\circ} \mathrm{C}$, relative humidity of $60 \pm 10 \%$ and photoperiod of 12 hours (adapted from GODOY et al., 2010).

A completely randomized design was used, consisting of 10 treatments, with 30 replications represented by 30 first-instar larvae of the species.

The larvae used were fed ad libitum with eggs of Anagasta kuehniella, Zeller (Lepidoptera: Pyralidae) until pupal stage, and remained under the same environmental conditions until adult emergence. After sex identification, these adults were divided into couples and kept in cylindrical cages of transparent Polyvinyl Chloride (PVC) $(\varnothing=10 \mathrm{~cm}$ and height $=20 \mathrm{~cm})$ internally covered with red suede paper as substrate for oviposition.

The cages containing the pair of insects were 
replaced with new ones three times a week, after the pre-oviposition period, and the number of eggs per female was counted, grouping a sample of 100 eggs per treatment of the subsequent generation in microtiter plates type Enzyme linked Immuno Sorbent Assay (ELISA), covered with the transparent PVC film and kept under the same experimental conditions, until the hatching of eggs.

Table 1. Insecticides used in commercial crops of muskmelon, evaluated through laboratory toxicity tests on first-instar larvae of $C$. genanigra.

\begin{tabular}{lccc}
\hline Commercial names & Active ingredient & Rate* & Chemical Group \\
\hline Focus WP & Clothianidin & 0.1 & Neonicotinoids \\
Chess 500WG & Pimetrozina & 0.25 & Piridina Azometina \\
Karate Zeon 50 CS & Lambda-Cialotrina & 0.025 & Piretroide \\
Premio & Clorantraniliprole & 0.0025 & Antranilamida \\
Rumo & Indoxacarbe & 0.036 & Oxadiazina \\
Cordial 100 & Piriproxifem & 0.1 & Éter Piridiloxipropilico \\
Connect & Beta-Ciflutrina/ Imidacloprido & $0.0625+0.5$ & Piretroide/ Neonicotinóide \\
Evidence 700 WG & Imidacloprido & 1.05 & Neonicotinóide \\
Akito & Beta-Cipermetrina & 0.04 & Piretroide \\
\hline
\end{tabular}

*Concentration rate used for the evaluations, expressed in grams of the active ingredient per liter of water.

The variables evaluated were mortality at all stages of development, duration of each instar, pupal survival, sex ratio, fecundity and viability of eggs from adults of the insects evaluated in the bioassay.

Statistical analyzes were performed using the software R (R CORE TEAM, 2016). The viability of eggs, survival and duration of the phases were checked for homogeneity of variances and normality of the data. When the data did not meet assumptions of normality and homogeneity, they were analyzed by the nonparametric test Kruskal-Wallis. The $\chi^{2}$ test for equality of proportions was used to calculate the sex ratio, assuming a ratio of 1:1 and using the sex ratio of formula (sex ratio $=$ number of females $/$ number of females + number of males). The total insect mortality during the experiment was corrected by the formula of Abbott (1925).

After evaluation of toxicity, the products were classified into toxicological classes [class $1=$ harmless $(\mathrm{E}<30 \%)$, class $2=$ slightly harmful $(30 \leq \mathrm{E} \leq 79 \%)$, class $3=$ moderately harmful $(\mathrm{E}=80-99 \%)$ and class $4=$ harmful $(\mathrm{E}=>99 \%)$ ] depending on the mortalities found by the total effect formula described by Overmeer (1988).

\section{RESULTS AND DISCUSSION}

The highest mortality found in treatments with insecticide application was found in the first-instar larvae of Chrysoperla genanigra. The treatments presented significant differences in the duration of development stages of the $C$. genanigra, with duration of the first instar of larvae ranging from 1.9 to 4.6 days (Table 2).

The duration of the first-instar larvae of the treatment with clothianidin were statistically similar to the pymetrozine, and both were statistically different than the control. The treatment with lambda-cyhalothrin prolonged the duration of the first-instar of larvae, while the treatments with pymetrozine and clothianidin delayed it.

Lambda-cyhalothrin is an insecticide from the pyrethroid chemical group, which acts on nervous system, affecting sodium channels, with a toxic action called knockdown, however, it has low residual toxicity (SANTOS; AREAS; REYES, 2007). This effect is often preceded by involuntary shaking of the thoracic appendages of the insects, which were visually observed during the experiment. This insecticide cause an immediate paralysis, however, since they not accumulate in the tissues of the organisms, it is readily metabolized, which may have caused a rapid detoxification of the specimens and no effect in subsequent development stages (HEMINGWAY, 2000).

Pymetrozine is an insecticide from the pyridine azomethine chemical group, which is a selective feed blocker, affecting the feeding behavior of insects, and is mainly used for control of sucking insects (ESASHIKA et al., 2016). This characteristic may have caused the shorter duration of the first instar of the larvae and development of the subsequent instars in this bioassay. The feed offered 
to the insects also had contact with the product residues, which may have intensified its effect. Similar effect occurs on the field, when products come in contact with insect-prey and are eaten by its predator. According to Parra (1991), in the larval stage, the quantity and quality of the food consumed affect the growth rate, time of development, survival and fecundity.

Clothianidin is an insecticide from the neonicotinoid chemical group, which acts directly on nicotinergic receptors, causing a nervous hyperactivity that hypothetically have induced an instinctive acceleration of development of larvae, as an escape tactic, minimizing its energy losses and ensuring its survival (TOMIZAWA; CASIDA, 2005).

Deltamethrin has the same mode of action of the lambda-cyhalothrin. According to Godoy et al. (2004), eggs of Chrysoperla externa (Hagen) (Neuroptera: Chrysopidae) have tolerance to this product, with average survival of $38.3 \%$, while the average survival of second $(96.7 \%)$ and third instars $(98.6 \%)$, and pupa from treated eggs $(100 \%)$ were not affected. These authors also evaluated the effect of this product on first and second instar larvae, which presented high mortality, failing to reach their subsequent development stage, thus classifying it as harmful, reinforcing the importance of toxicity bioassays at the different development stages for these predators.

Freire et al. (2014) found similar results to the present study with application lambda-cyhalothrin followed by artificial rain to evaluate the residual toxicity of the product in second-instar larvae of $C$. externa. These authors reported no effect of the compound in the duration of larval and pupal stages, since its residue lost its toxic effect, not changing the biological parameters evaluated, thus this insecticide was classified as harmless (toxicological class 1), even by the IOBC.

The treatments with beta-cypermethrin, imidacloprid, pyriproxyfen and chlorantraniliprole were the only products statistically similar to the control regarding the duration of the second-instar of the larvae (Table 2). The different results found may be related to the capacity of the insects to metabolize the insecticides. According to Hemingway (2000), several enzymes in the insects are related to detoxification, converting toxic into non-toxic molecules, which are readily removable from the body.

The effects of the clothianidin, indoxacarb and lambda-cyhalothrin were statistically equal regarding the period of the third instar, with greater reduction of this phase duration compared with the other treatments (Table 2). Some neonicotinoids, as the clothianidin, have greater penetration capacity and accumulation in the cuticle of insects, into fatty tissues for example, and can affect their development and subsequent generations (TOMIZAWA; CASIDA, 2005), which probably have affected the duration of the last larval instar of the insects treated with clothianidin.

Despite these insecticides are statistically similar regarding the duration of the third instar, they act on different active sites in the nervous system. Clothianidin belongs to the chemical group of neonicotinoids, acting directly on the postsynaptic receptors of the acetylcholine, while the indoxacarb belongs to the group of oxadiazines, acting as modulator of sodium channels in the axonal cell, and the lambda-cyhalothrin is a pyrethroid that acts by modulating sodium channel (SANTOS; AREAS; REYES, 2007)

Pyriproxyfen was statistically similar to the control, however different from the others regarding the period of the third instar, with the highest duration of this development phase (Table 2). Pyriproxyfen belongs to the group of juvenile hormone analogues, affecting the action of growth regulator hormones (MIRANDA; BORTOLI; TAKAHASHI, 2012), indirectly inhibiting the activity of the prothoracic gland. The efficiency of these insecticides is greater on development phases in which juvenile hormones are high in the insect hemolymph, preventing them to develop to their next phase, leading to premature death (DHADIALLA; CARLSON; LE, 1998). However, the slow initial action of these products is offset by a long residual toxicity, which can delay the death of infected insects (MARI; GUERREIRO, 2015). A longer larval period means a greater number of prey consumed by predators, however, the action of this product reduced the insect activity during larval stages, affecting the feeding behavior of insects, with consequent mortality all insects of this treatment. Velloso et al. (1999) tested the pyriproxyfen toxicity in first, second and third-instar larvae of $C$. externa and found the residual toxicity effect inhibiting adult emergence.

Maia et al. (2014) evaluated the persistence and side effects of application of lambda-cyhalothrin and pyriproxyfen followed by artificial rain on third-instar larvae of $C$. externa, and classified these products as harmless (class 1), since they not influenced the survival, fecundity and fertility of insects. However, the pupal viability was affected by these insecticides.

Imidacloprid stood out regarding the pupal stage duration, with a longer period than the other insecticides, and the indoxacarb presented opposite effects. Chlorantraniliprole was the only insecticide with no significant difference to the control regarding the duration of the adult phase (Table 2). 
B. K. A. SILVA et al.

Table 2. Mortality, duration (days) of the phases (first, second and third instars, pupa and adult) and sex ratio (mean \pm standard error) of $C$. genanigra insects depending on different insecticides applied to them at the first-instar.

\begin{tabular}{|c|c|c|c|c|c|c|c|c|c|c|c|}
\hline \multirow{2}{*}{ Treatment } & \multirow{2}{*}{$\begin{array}{c}\text { Initial } \\
\text { number } \\
\text { of larvae }\end{array}$} & \multicolumn{2}{|c|}{$1^{\circ}$ instar $^{1}$} & \multicolumn{2}{|c|}{$2^{\circ}$ instar $^{1}$} & \multicolumn{2}{|c|}{$3^{\circ}$ instar $^{1}$} & \multicolumn{2}{|r|}{ Pupa $^{1}$} & \multirow{2}{*}{ Adult $^{1}$} & \multirow{2}{*}{$\begin{array}{l}\text { Sex } \\
\text { ratio }^{2 *}\end{array}$} \\
\hline & & $\mathrm{M}^{3}$ & $\mathrm{D}^{4}$ & $\mathrm{M}^{3}$ & $\mathrm{D}^{4}$ & $\mathrm{M}^{3}$ & $\mathrm{D}^{4}$ & $\mathrm{M}^{3}$ & $\mathrm{D}^{4}$ & & \\
\hline Control & 30 & 3 & $3.2 \pm 0.2 \mathrm{ab}$ & 1 & $2.9 \pm 0.6 \mathrm{a}$ & 4 & $6.3 \pm 0.9 \mathrm{ab}$ & 1 & $6.3 \pm 0.8 \mathrm{ab}$ & $25.1 \pm 4.8 \mathrm{a}$ & $0.32 *$ \\
\hline Clothianidin & 30 & 23 & $2.2 \pm 0.3 \mathrm{c}$ & 1 & $0.6 \pm 0.2 \mathrm{~d}$ & 1 & $1.0 \pm 0.4 \mathrm{e}$ & 1 & $1.8 \pm 0.8 \mathrm{de}$ & $4.4 \pm 2.9 \mathrm{c}$ & $1.00 *$ \\
\hline Pymetrozine & 30 & 30 & $1.9 \pm 0.1 \mathrm{c}$ & - & - & - & - & - & - & - & - \\
\hline $\begin{array}{l}\text { Lambda- } \\
\text { cyhalothrin }\end{array}$ & 30 & 15 & $4.6 \pm 0.5 \mathrm{a}$ & 2 & $1.3 \pm 0.3 \mathrm{~cd}$ & 1 & $2.1 \pm 0.5 \mathrm{de}$ & 2 & $3.5 \pm 0.8 \mathrm{~cd}$ & $9.5 \pm 3.7 \mathrm{bc}$ & 0.56 \\
\hline Chlorantraniliprole & 30 & 5 & $2.9 \pm 0.2 \mathrm{~b}$ & 0 & $2.3 \pm 0.3 \mathrm{ab}$ & 0 & $4.3 \pm 0.4 \mathrm{bc}$ & 1 & $6.8 \pm 0.6 \mathrm{ab}$ & $27.4 \pm 4.1 \mathrm{a}$ & $0.22 *$ \\
\hline Indoxacarb & 30 & 18 & $3.8 \pm 0.3 \mathrm{ab}$ & 8 & $1.5 \pm 0.5 \mathrm{~cd}$ & 3 & $1.0 \pm 0.6 \mathrm{e}$ & 1 & $0.2 \pm 0.2 \mathrm{e}$ & - & - \\
\hline Pyriproxyfen & 30 & 6 & $3.1 \pm 0.2 \mathrm{ab}$ & 4 & $2.2 \pm 0.3 \mathrm{ab}$ & 20 & $12.8 \pm 1.9 \mathrm{a}$ & - & - & - & - \\
\hline $\begin{array}{l}\text { Beta-cyfluthrin+ } \\
\text { imidacloprid }\end{array}$ & 30 & 15 & $3.5 \pm 0.4 \mathrm{ab}$ & 1 & $1.7 \pm 0.4 \mathrm{bc}$ & 3 & $3.5 \pm 0.8 \mathrm{~cd}$ & 2 & $3.2 \pm 0.8 \mathrm{~cd}$ & $12.5 \pm 4.5 \mathrm{bc}$ & 0.56 \\
\hline Imidacloprid & 30 & 6 & $3.2 \pm 0.2 \mathrm{ab}$ & 1 & $2.1 \pm 0.3 \mathrm{ab}$ & 3 & $5.5 \pm 0.6 \mathrm{ab}$ & 15 & $7.5 \pm 1.0 \mathrm{a}$ & $3.4 \pm 1.6 \mathrm{c}$ & $0.80^{*}$ \\
\hline Beta-cypermethrin & 30 & 8 & $3.8 \pm 0.3 \mathrm{ab}$ & 1 & $2.5 \pm 0.4 \mathrm{a}$ & 7 & $6.3 \pm 1.0 \mathrm{ab}$ & 1 & $3.6 \pm 0.8 \mathrm{bc}$ & $10.1 \pm 3.4 \mathrm{~b}$ & $0.82 *$ \\
\hline
\end{tabular}

${ }^{1}$ Values followed by the same letter in the columns do not differ by the nonparametric test Kruskal-Wallis at 0.05 significance level. ${ }^{2}$ Values followed by a * in the columns differ statistically from the expected ratio of $1: 1$ by the test for equal proportions $x^{2}$ at 0.05 significance level. ${ }^{4}$ Cumulative mortality in the development phase. ${ }^{5}$ Instar duration.

The insecticide beta-cyfluthrin+imidacloprid showed results statistically similar to the control for the duration of the first instar, however, they differed in all other development stages of the predator. Chlorantraniliprole was the most statistically similar insecticide to the control regarding the duration of the development stages. The treatment clothianidin presented the shortest durations in all development stages, especially for the second instar of larvae (Table 2).

Lambda-cyhalothrin

and beta-cyfluthrin+imidacloprid were the only insecticides with no statistical differences regarding the expected ratio of 1:1 for the sex ratio parameter by the Qui-square test (Table 1). The sex ratio data of emerged adults after the action of these products cannot be used as parameters for subsequent bioassays, since the accumulated mortality rate was high, and only four adults survived to the treatment with clothianidin and only five juveniles survived to the treatment with imidacloprid (Table 2).

Studies on sex ratio of another predator of the genus Chrysoperla, with similar eating habits (C. externa) was used as a parameter for the present experiment, given the lack of studies on selectivity of the $C$. genanigra species. Vilela et al. (2010) evaluated the application of spirodiclofen, fenpropathrin, sulfur and abamectin on pre-pupae of C. externa and found no effect on sex ratio, differing from the present study, probably because they are different species. The chlorantraniliprole was the only treatment that showed the minimum number of couples recommended by the IOBC for evaluation of sublethal effects, and pre-oviposition ( $4.7 \pm 0.2$ days) and viability of eggs $(84.16 \pm 1.9 \%)$ statistically similar to the control (5.2 \pm 0.3 days and $73.75 \pm 3.1 \%$, respectively) by the Kruskal-Wallis test at 0.05 significance level.

The number of eggs of females in the control treatment was, on average, 5.01 eggs female ${ }^{-1}$ day $^{-1}$, while in the chlorantraniliprole treatment it was 3.69 eggs female ${ }^{-1}$ day $^{-1}$. Studies about the toxicity of chemicals on this species are scarce and not yet published, however, a biology study conducted by Bezerra et al. (2012) showed that under temperature of $25^{\circ} \mathrm{C}$, relative humidity of $65 \% \pm 10$ and photoperiod of 12 hours, C. genanigra females had approximately 2.22 eggs female ${ }^{-1}$ day $^{-1}$. These values were lower than those found in the present study, probably because of the feed used by these authors in the larval stage, namely, eggs of Sitotroga cerealella Oliver, 1789 (Lepidoptera: Gelechiidae). These results may vary depending on the species and within species, since they are affected by edaphoclimatic factors and quantity and quality of food consumed.

Studies about selectivity of insecticides to the predator $C$. genanigra are also scarce and not yet published, thus a better discussion on the biological parameters evaluated was not possible, even on the average number of eggs per female, whose evaluation was not possible due to the sublethal effects of pesticides on the development stages after application.

According to the toxicological classification proposed by the IOBC, chlorantraniliprole was the only selective insecticide to first-instar larvae of C. genanigra, classified as harmless (Class 1) and thus, it is recommended for using in integrated pest management programs on muskmelon crops (Table 3).

The other products were classified as harmful for the first-instar larvae of the predator (Table 3), thus, the use of these products is not recommended 
to insects at this development stage and the conditions of the present experiment. Further researches must be carried out, evaluating other conditions, with combinations of insecticides on this species to achieve sustainable practices in muskmelon production with the use of this predator, since there was a high mortality rate of the progeny in laboratory conditions, which prevented the reproduction of the insects subjected to the treatments evaluated.

Table 3. Mortality (\%), average number of eggs day ${ }^{-1}$ female $^{-1}$, fertility of eggs (\%) and total effect (E) caused by treatments with insecticides applied to first-instar larvae of $C$. genanigra, followed by the toxicity classification of the compounds proposed by the IOBC.

\begin{tabular}{lcccccccc}
\hline Treatments & $\begin{array}{c}\text { Initial } \\
\text { number } \\
\text { of larvae }\end{array}$ & $\begin{array}{c}\text { Total } \\
\text { mortality }\end{array}$ & $\mathrm{M} \%^{1}$ & $\mathrm{MC}^{2}$ & $\mathrm{R}^{3}{ }^{3}$ & $\mathrm{R} \%^{4}$ & $\mathrm{E}^{5}{ }^{5}$ & Class $^{6}$ \\
\hline Control & 30 & 9 & 30 & - & 5.01 & 0.73 & - & - \\
Clothianidin & 30 & 26 & 86.67 & 80.96 & - & - & - & 4 \\
Pymetrozine & 30 & 30 & 100 & 100 & - & - & - & 4 \\
Lambda-cyhalothrin & 30 & 20 & 66.67 & 52.39 & - & - & - & 4 \\
Chlorantraniliprole & 30 & 6 & 23.33 & - & 3.69 & 0.84 & 6.79 & 1 \\
Indoxacarb & 30 & 30 & 100 & 100 & - & - & - & 4 \\
Pyriproxyfen & 30 & 30 & 100 & 100 & - & - & - & 4 \\
Beta-cyfluthrin + & 30 & 21 & 70 & 57.14 & - & - & - & 4 \\
imidacloprid & 30 & 25 & 83.33 & 76.19 & - & - & - & 4 \\
Imidacloprid & 30 & 17 & 63.33 & 47.61 & - & - & - & 4 \\
Beta-cypermethrin & 30 & & & & & & & \\
\hline
\end{tabular}

${ }^{1}$ accumulated mortality (\%) until the emergence of adults. ${ }^{2}$ accumulated mortality (\%) until the emergence of adults, corrected by the Abbott formula (1925). ${ }^{3}$ Average numbers of eggs day ${ }^{-1}$ female ${ }^{-1}$ from the beginning of oviposition. ${ }^{4}$ Viability (\%) of eggs during eight consecutive weeks. ${ }^{5}$ Total effect of the compounds $(\%)$. ${ }^{6}$ Toxicity class of IOBC: class $1=$ innocuous $(<30 \%)$ and class $4=$ harmful $(>99 \%)$.

Tavares (2013) applied the same insecticides on eggs of $C$. externa, under the same environmental conditions and found different toxicological classifications for all compounds. Teles (2014), also evaluated the same products and found the same toxicological classification for clothianidin, lambda-cyhalothrin, chlorantraniliprole, indoxacarb, pyriproxyfen, beta-cyfluthrin+imidacloprid, imidacloprid and beta-cypermethrin by applying them on eggs of the predator $C$. genanigra. These studies reinforce the importance of evaluating toxicity on the different stages and predator species, since different responses may be found under the same environmental conditions, even when using the same active ingredients.

Bueno and Freitas (2001) evaluated the toxicity of imidacloprid on first-instar larvae of C. Externa and found $100 \%$ mortality. Godoy et al. (2004) evaluated the mortality and reproduction of adults of $C$. externa from treated eggs with deltamethrin, and classified this insecticide as Class 2 (slightly harmful), differing from the pyrethroids in the present study, which were classified as harmful.

Pasini et al. (2014) evaluated the selectivity of insecticides to $C$. externa pupae and classified the lambda-cyhalothrin, zeta-cypermethrin, permethrin and beta-cyfluthrin as innocuous to the pupa phase, differing from the results for lambda-cyhalothrin found in the present study.

Godoy et al. (2010) applied pyriproxyfen and imidacloprid to $C$. externa adults and found different toxicological classes, innocuous (pyriproxyfen) and slightly harmful (imidacloprid).

These different results are probably due to the use of different species in the bioassays, showing the particular physiological responses of each species. According to Godoy et al. (2010), some insecticides probably present specific toxicity to certain species of Chrysopidae, hindering the physiological selectivity of these compounds, involving their processes of absorption, penetration, transport and activation in tissues and vital organs of the target organisms.

Further evaluations of the effect of the products classified as harmful under semi-field and field conditions on different development stages of the predator is needed to confirm the toxicity of these products and their recommendation for or exclusion from IPM programs in muskmelon crops.

\section{CONCLUSIONS}

Chlorantraniliprole was the only insecticide considered selective to first-instar larvae of Chrysoperla genanigra, thus, it is recommended for integrated pest management programs in muskmelon crops. The other insecticides evaluated were considered harmful, and further toxicity studies on them are recommended. 


\section{REFERENCES}

ABBOTT, W. S. A method of computing the effectiveness of insecticide. Journal of Economic Entomology, Lanham, v. 18, n. 1, p. 265-267, 1925.

ARAÚJO, V. F. S; CAMPOS, D. F. A cadeia logística do melão produzido no Agropolo Fruticultor Mossoró/Açu. Revista Econômica do Nordeste, Fortaleza, v. 42, n. 3, p. 505-529, 2011.

BEZERRA, C. E. S. et al. Biology and thermal requirements of Chrysoperla genanigra (Neuroptera: Chrysopidae) reared on Sitotroga cerealella (Lepidoptera: Gelechiidae) eggs. Journal of Biological Control, Bangalore, v. 60, n. 2, p. 113-118, 2012.

BROOKS, S. J.; BARNARD, P. C. The green lacewings of the world: a generix review (Neuroptera: Chrysopidae). Bulletin of the British Museum of Natural History (Entomology series), Londres, v. 59, n. 1, p. 117-286, 1990.

BUENO, A. F.; FREITAS, S. Efeito do hexythiazox e imidacloprid sobre ovos e larvas de Chrysoperla externa (Hagen) (Neuroptera: Chrysopidae). Revista Ecossistema, Espírito Santo do Pinhal, v. 26, n. 1, p. 74-76, 2001.

CASTILHOS, R. V. et al. Seletividade de agrotóxicos utilizados em pessegueiro sobre ovos e pupas do predador Chrysoperla externa. Ciência Rural, Santa Maria, v. 44, n. 11, p. 1921-1928, 2014.

CHAGAS, F. et al. Controle biológico em sistema orgânico de produção por agricultores da cidade de Maringá (Paraná, Brasil). Ciência e Natura, v. 38, p. $637-647,2016$.

DHADIALLA, T. S.; CARLSON, G.; LE, D. New insecticides with ecdysteroidal and juvenile hormone activity. Annual Review of Entomology, Palo Alto, v. 43, s/n., p. 545-569, 1998.

ESASHIKA, D. A. S. et al. Suscetibilidade de adultos de Bemisia tabaci biótipo B a inseticidas. Horticultura Brasileira, Vitória da Conquista, v. 34, n. 2, p. 189-195, 2016.

FOERSTER, L. A. Seletividade de inseticidas a predadores e parasitóides. In: PARRA, J. R. P. (Ed.). Controle biológico no Brasil: parasitoides e predadores. São Paulo: Manole, 2002. cap. 6, p. 95-114.

FREIRE, B. C. et al. Ação residual de inseticidas aplicados em plantas de algodão quando submetidas à aplicação de chuva artificial sobre larvas de segundo instar de Chrysoperla externa (Hagen, 1861) (Neuroptera: Chrysopidae). In: XXV CONGRESSO BRASILEIRO DE ENTOMOLOGIA, 2014, Goiânia, Anais... Goiânia, UFG, 2014. Disponível em: <http:// www.cbe2014.com.br/anais/lista_area_14.htm>.

Acesso em: 12 jun. 2016.

FREITAS, S.; MORALES, A. C. Indicadores morfométricos em cabeças de espécies brasileiras de Chrysoperla (Neuroptera, Chrysopidae). Revista Brasileira de Entomologia, São Paulo, v. 53, n. 4, p. 499-503, 2009.

FREITAS, S. O uso dos crisopídeos no controle biológico de pragas. Jaboticabal, SP: Funep, 2001. $66 \mathrm{p}$.

FREITAS, S.; PENNY, N. D. The green lacewings (Neuroptera: Chrysopidae) of Brazilian agro-ecosystems. Proceedings of the California Academy of Sciences, San Francisco, v. 52, n. 19, p. 245-395, 2001.

GODOY, M. S. et al. Seletividade de inseticidas utilizados na cultura dos citros para ovos e larvas de Chrysoperla externa (Hagen, 1861) (Neuroptera: Chrysopidae). Neotropical Entomology, Londrina, v. 33, n. 5, p. 639-646, 2004.

GODOY, M. S. et al. Seletividade fisiológica de inseticidas em duas espécies de crisopídeos. Pesquisa Agropecuária Brasileira, Brasília, v. 45, n. 11, p. 1253-1258, 2010.

HASSAN, S. A. et al. Results of the sixth joint pesticide testing programme carried out by the IOBC/WPRS - Working Group "Pesticides and Beneficial Organisms". Entomophaga, Paris, v. 39, n. 1, p. 107-119, 1994.

HEMINGWAY, J. The molecular basis of two contrasting metabolic mechanisms of insecticide resistance. Insect Biochemistry and Molecular Biology, Califórnia, v. 30, n. 11, p. 1009-1015, 2000 .

INTERNATIONAL ORGANIZATION FOR BIOLOGICAL CONTROL/WEST PALAERCTIC REGIONAL SECTION - IOBC/WPRS. Working Group "Pesticides and Beneficial Organisms", Guidelines for testing the effects of pesticides on beneficial organisms: description of test methods. Bulletin IOBC/WPRS, v. 15, n. 3, p. 1-186, 1992.

LIMA, A. C. C. et al. Diagnóstico sobre o uso do MIP nas principais áreas produtoras de melão dos Estados do Rio Grande do Rio Grande do Norte e Ceará. Revista Agroambiente, Boa Vista, v. 6, n. 2, p. 172-178, 2012. 
LIMA, T. C. C.; BUENO, V. H. P.; ALENCAR, J. A. Pragas do Meloeiro. Revista Plasticultura, Campinas, v. 6, n. 28, p. 8-11, 2013.

MAIA, J. B. et al. Influência da chuva artificial na persistência e efeitos secundários de inseticidas utilizados na cultura do algodoeiro sobre larvas de terceiro instar de Chrysoperla externa (Hagen, 1861) (Neuroptera: Chrysopidae). In: XXV CONGRESSO BRASILEIRO DE ENTOMOLOGIA, 2014, Goiânia, Anais... Goiânia, UFG, 2014.

MAIA, J. B. et al. Lethal and sublethal effects of pesticides on Chrysoperla carnea larvae (Neuroptera: Chrysopidae) and the influence of rainfastness in their degradation pattern over time. Ecotoxicology, London, v. 25, n. 5, p. 1-12, 2016.

MARI, M. A.; GUERREIRO, J. C. Inseticidas reguladores de crescimento de insetos: formas de utilização e potencialidades para o manejo integrado de pragas. Journal of Agronomic Sciences, Umuarama, v. 4, Sup., p. 360-374, 2015.

MIRANDA, J. E.; BORTOLI, S. A.; TAKAHASHI, R. Desenvolvimento e produção de seda do Bombyx mori L. exposto a análogos do hormônio juvenil. Arquivos do Instituto Biológico, São Paulo, v. 79, n. 1, p. 91-96, 2012.

OVERMEER, W. P. J. Laboratory method for testing side-effects of pesticides on the predacious mites Typhlodromus pyri and Amblyseius potentillae (Acari: Phytoseiidae). IOBC/WPRS Bulletin, Montfovet, v. 11, n. 4, p. 65-69, 1988.

PARRA, J. R. P. Consumo e utilização de alimentos por insetos. In: PANIZZI, A. R.; PARRA, J. R. P. (Eds.). Ecologia nutricional de insetos e suas implicações no manejo de pragas. São Paulo: Manole, 1991, cap. 2, p. 9-65.

PASINI, R. A. et al. Efeito de inseticidas piretróides registrados para a cultura do trigo sobre pupas de Chrysoperla externa (Hagen, 1861) (Neuroptera: Chrysopidae). In: XXV CONGRESSO BRASILEIRO DE ENTOMOLOGIA, 2014, Goiânia. Anais... Goiânia: SEB, 2014.

PICANÇO, M. Manejo integrado de pragas. Viçosa, MG: UFV, 2010, 146 p.

R CORE TEAM. A language and environment for statistical computing. 2016. R Foundation for StatisticalComputing, Austria. Disponível em: $<$ http://www.R-project.org/>. Acesso em 14 de fev. 2016.

SANTOS, M. A. T.; AREAS, M. A.; REYES, F. G. R. Piretróides - uma visão geral. Alimentos e
Nutrição, Araraquara, v. 18, n. 3, p. 339-349, 2007.

SOARES, J. J.; ALMEIDA, M. G. M. Metodologia para criação de Chrysoperla externa. Campina Grande, PB: Embrapa Algodão, 2001, 3 p. (Comunicado Técnico 135).

SOBRINHO, R. B. et al. Manejo Integrado de Pragas no meloeiro. Fortaleza: Embrapa Agroindústria Tropical, 2011. Disponível em: $<$ http://www.cnpat.embrapa.br/

download_publicacao.php?id=333. $>$. Acesso em: 27 set. 2016.

TAVARES, P. K. A. Toxicidade de inseticidas utilizados na cultura do meloeiro a Chrysoperla externa (Hagen, 1861) (Neuroptera: Chrysopidade). 2013. 57 f. Dissertação (Mestrado em fitotecnia: Área de concentração em Entomologia Agrícola) - Universidade Federal Rural do Semi-Árido, Mossoró 2013.

TELES, D. Seletividade de inseticidas utilizados no meloeiro sobre Chrysoperla genanigra Freitas e Chrysoperla externa Hagen (Neuroptera: Chrysopidae). 2014. 73 f. Dissertação (Mestrado em Horticultura Tropical: Proteção de Plantas) - Universidade Federal de Campina Grande, Paraíba, 2014.

TOMIZAWA, M.; CASIDA, J. E. Neonicotinoid insecticide toxicology: mechanisms of selective action. Annual Review of Pharmacology and Toxicology, Palo Alto, v. 45, n. 1, p. 247-248, 2005.

VELlosO, A. H. P. P. et al. Efeitos de compostos reguladores de crescimento de insetos sobre larvas e adultos de Chrysoperla externa (Hagen, 1891) (Neuroptera: Chrysopidae). Ciência e Agrotecnologia, Lavras, v. 23, n. 1, p. 96-101, 1999.

VILELA, M. et al. Seletividade de acaricidas utilizados em cafeeiro para pré-pupas e adultos de Chrysoperla externa (Hagen, 1861) (Neuroptera: Chrysopidae). Arquivos do Instituto Biológico, São Paulo, v. 77, n. 3, p. 505-510, 2010. 